\title{
A Move towards Maturity: Scott Fitzgerald's The Crack-Up
}

\author{
A. Banerjee \\ Kobe Jogakuin University
}

\begin{abstract}
When Fitzgerald's The Crack-Up essays first appeared in 1936-in the "pre-confessional" critical climate-they were received with disapprobation and sometimes condemnation even by his friends. Hemingway thought that they were "miserable" and Dos Passos felt Fitzgerald should not have made a public display of his "going to pieces." But I think that the essays are not so much as confessional as attempts at soul-searching and selfexamination. Fitzgerald recognizes in them the fact that he must undergo a "spiritual conversion," that he must, as a novelist, write more objectively. During the short period, between the writing of these essays and his death, he did embark on a new, and as it turned out, a more mature strategy as an artist. The Crack-Up gives us an insight into the kind of novelist that he would have become, had he lived longer.
\end{abstract}

When F. Scott Fitzgerald's three autobiographical articles-“The Crack-Up," "Pasting It Together," and "Handle It with Care"-appeared in Esquire in February, March, and April 1936 , they were largely seen as a prime example of the literature of self-expression. While discussing them soon after Fitzgerald's death, the novelist Glenway Wescott predicted, correctly, that confessionalism "might be the next esthetic issue and new mode of American letters. It is American enough: our greatest fellows, such as Franklin and Audubon and Thoreau and Whitman, were self-expressers in so far as they knew themselves" (217). It is true that the confessional writers of the sixties, poets like Lowell, Berryman and Plath, had turned self-expression into art. They gained critical recognition for the sincerity with which they re-enacted in their poems their own painful, and sometimes violent, experiences as a result of their various mental illnesses. But Fitzgerald did not see any aesthetic or artistic possibilities in his essays of self-expression. In writing them, he was mainly interested in explaining in his essays-which he saw collectively as a "short history" (388) - the circumstances that led to his breakdown, both physical and mental. I suggest that by writing this "history," Fitzgerald underwent a chastening 
experience in the sense that he was able to analyse his past as a writer in the context of the demands of the present. He came to realize that he would have to change according to the changing circumstances of his life, and presumably write differently. Unfortunately, his health gave way before he could accomplish such a change.

In a letter (February 1938) of sympathy to a dejected writer, Roger Garis, Fitzgerald explained that a couple of years earlier - the time when he wrote "The Crack-Up"-he too had fallen a victim to dejection and melancholia. But he was careful to insist that it was a temporary illness rather than a permanent pathological condition:

In several ways, I am familiar with the melancholia you describe. Myself, I had what amounted to a nervous breakdown which never, however, approached psychosis. My wife, on the contrary, has been a mental patient off and on for seven years and will not be well again, so I have a very detached point of view on the subject. (Letters 568)

As for the reasons for this, Fitzgerald thought that they were "the usual combination of circumstances" which could be interpreted differently by different people: a "prejudiced enemy" might have attributed it to drink, a "fond mama" to ill-luck, the bank-manager to financial mismanagement and the psychiatrist to "a nervous collapse." He himself thought that "it was perhaps partly all those things. .." (Letters 549-50). I myself am inclined to believe that Fitzgerald's mood of depression had its origins in his stormy marriage and that it came to a head in the early thirties. Many of the poeple who knew Fitzgerald had felt that Zelda was a woman of an unstable personality. Fitzgerlad's Princeton classmate Alexander McCraig met him and his wife soon after their wedding, and wrote down the following impressions in his diary:

Called on Scott Fitz and his bride. Latter temperamental Southern Belle. Chews gum-shows knees. I do not think marriage can succeed. Both drinking heavily. Think they will be divorced in 3 years. Scott writing something big-then die in a garret at 32 . (Turnbull 119)

And Rebecca West, who first met the Fitzgeralds when they were living in Great Neck, wrote, "I was terrified not exactly of, but for, his wife. I knew Zelda was very clever but from the very first moment I saw her I knew she was mad" (Turnbull 341). Indeed, the signs of Zelda's mental illness became increasingly more noticeable and, in April 1930, she had the first of her many breakdowns. She was admitted to a sanitorium in Prangins in Switzerland and her case was diagnosed as schizophrenia. By 1934, she had had her third breakdown, leading Fitzgerlad to believe that she was unlikely to recover. He wrote in his Notebooks: "I left my capacity for hoping on the little road that led to Zelda's sanitarium" (204).

In retrospect, perhaps it is undeniable that both Zelda's condition and her behaviour had a damaging effect on Fitzgerald's life and career as an artist. Hemingway pointed out in A Moveable Feast that he had felt that "Zelda was jealous of Scott's work" (163) and that she had tried to keep him away from it. Fitzgerald had also felt that Zelda did not offer help or encouragement to him as a writer: "A strange thing was that I could never convince 
Zelda that I was a first rate writer. She knew I could write well, but she did not recognize how well. When I was making myself from a popular writer to a serious writer, 'a big shot,' she did not try to understand or try to help me" (Bruccoli 193-4). However, Fitzgerald's own responsibility in this matter can hardly be underestimated. His breakdown was closely related to his alcoholism for which Zelda should not be blamed. According to his latest biographer, Matthew Bruccoli, Fitzgerald was an "incipient alcoholic" (135) right from the start, and by 1923-24 he "had progressed from a party-drinker to a steady drinker with increasingly erratic behaviour" (185). Eventually he did become an alcoholic. He also suffered, as is well known, from tuberculosis as well as a heart condition which finally resulted in his premature death.

What led Fitzgerlad to write The Crack-Up pieces was a combination of all these circumstances but perhaps Bruccoli is right in believing that the most immediate and pressing one was his inability to write in his old (at least, commercially successful) manner:

[I]n 1935 his style was losing its distinction because he didn't have time to polish his prose. His plots had become loosely constructed and his characters were unconvincing. He was a sick, tired, depressed man of thirty-eight who thought he had lost the capacity to feel intensely. For the first time in his career he was producing really hack work-as distinguished from commercial work. (401)

As a result, his agent Harold Ober found it difficult to sell Fitzgerald's stories "at any price" (Turnbull 271). Turnbull believes that a part of the reason why Fitzgerald was not able to write saleable stories was the gap between what the magazines wanted and what he could deliver: "How, in his present mood [italics added], could he put his heart into tales of young love?" (273). In the past he did write, even against his natural artistic propensities, what his audience wanted. But, as Arthur Mizener has noted, "[i]t constantly exacerbated him that, as he once wrote to his agent and friend, Harold Ober, 'a cheap story like The Popular Girl... written in a week while the baby was being born brings $\$ 15,00.00$ \& a genuinely imaginative thing into which I put three weeks' real enthusiasm like The Diamond in the Sky . . brings not a thing"' (3). He had told Hemingway too that he originally wrote what he thought were good stories but that he changed them in order to make them saleable. When Hemingway told him that it was "whoring," Fitzgerald admitted it was "whoring but that he had to do it as he made money from the magazines to have money ahead to write decent books" (A Moveable Feast 136).

Fitzgerald had high literary ambitions and standards right from the very beginning, and he looked up to literary critics for approval and when they found blemishes and shortcomings in his writings, he accepted their remarks as constructive criticism. For instance, when Edmund Wilson pointed out, in an article, that This Side of Paradise was “"very immaturely imagined,' illiterate and devoid of intellectual content," Fitzgerald wrote to Maxwell Perkins, "Wilson's article about me in the March [issue of Bookman] is superb ... it's the first time I've been done at length by an intelligent and sophisticated man and I appreciate it-jeers and all" (Turnbull 128). There is therefore every reason to suppose that, as Lionel Trilling has remarked, "Fitzgerald consciously placed himself in 
the line of the great [writers]" (250) and he was condescending towards his own as well as others' commercial successes: for instance, speaking about Gone with the Wind (on which he had worked while in Hollywood), he said, "I felt no contempt for it but only a certain pity for those who considered it the supreme achievement of the human mind" (Letters 50).

"The supreme achievement of the human mind" was obviously the ideal that Fitzgerald had set for himself as a writer. But the tragedy of his life was that he never achieved the financial security nor the congenial personal circumstances that might have enabled him to achieve it. At the time of his crack-up, he seems to have felt that he was no longer able to write even the kind of stories that the magazines would accept. This drying up of his source of income, together with Zelda's deteriorating condition and his own failing health, made his prospects very bleak indeed. Therefore,

[o]ne night in November 1935, he packed a brief suitcase and fled to Hendersonville-a little town between Asheville and Tyron-to think out why "I had developed a sad attitude to sadness, a melancholy attitude to melancholy and a tragic attitude to tragedy - why I had become identified with the objects of my horror or compassion." Eating twenty-cents meals and washing his clothes in a two-dollar room at Skylands Hotel, he wrote an essay called "The Crack-Up," and returning to Baltimore "for what Xmas [was] to be found there," he wrote two more in the same vein. (Turnbull 273)

Fitzgerald's essays initially received disapprobation, sometimes downright condemnation even from his friends. After the appearance of the second essay, Hemingway wrote to Max Perkins, that the "Esquire pieces seem to me to be so miserable. There is another one coming too. I always knew he couldn't think-he never could—but he had a marvellous talent and the thing is to use it-not whine in public" (Letters 437-8). Dos Passos also disapproved of Fitzgerald's "whining" in public. He wrote to him: "We're living in one of the damndest tragic moments in history-if you want to go to pieces I think it's absolutely o.k. but I think you ought to write a novel about it (and probably will) instead of spilling it in little pieces for Arnold Gingrich" (Bruccoli 405).

It is ironic that while both these writers accused Fitzgerald of revealing himself too nakedly in public, subsequent critics, like Milton Hindus, have felt (in the appropriately congenial critical climate of the sixties) that Fitzgerald was not fully confessional in these writings:

There are deficiencies in it purely as confession. It does not contain enough close-ups of actual experience... The greatest confessional writing contains more concrete evidence than does The Crack-Up that its author was burned in the fire of reality. No doubt Fitzgerald found himself immolated in such a fire once, but the precise point at which the flame entered into him has been forgotten (or, at least, not revealed) and only the general impression of excruciating pain has remained. (90)

But such readings miss the central purpose of "The Crack-Up" essays. They are not 'confessional' in the sense the word is now used in literary criticism. They are more an attempt on the part of the writer to analyse and examine his past life and his attitudes and 
ideals as a novelist. This fact also saves the essays from becoming self-pitying and morbid - the cardinal weaknesses of much of the confessional writings of the post-war years.

Almost at the very beginning of his first essay, "The Crack-Up" (388-93), it is clear that Fitzgerald's intelligence is alert and is at work: he makes "the general observation" that "the test of a first-rate intelligence is the ability to hold two opposed ideas in the mind at the same time, and still retain the ability to function. One should, for example, be able to see that things are hopeless and yet be determined to make them otherwise." $\mathrm{He}$ believed that in his early life he had been such a man "of a first-rate intelligence" because, in his chosen profession of a writer, he had been able to dominate life "with intelligence and effort." Of course, he had failures and frustrations, he had suffered from "the common ills-domestic, professional and personal." But an intelligent awareness of the reality of life together with his fortitude made him determined to "succeed" in the face of "the inevitability of failure." In other words, he had the vision of a tragedian which was one of struggle and determination.

However, now he was becoming increasingly aware that he was not able to sustain his faith in such an ideal. The various circumstances of life which I mentioned earlier might account for this, leading him gradually to lose hope. Then, suddenly, his fears about his own deteriorating health were chillingly confirmed by his doctor, and this resulted in his melancholia and breakdown. In April 1935, his doctor had discovered that his lungs had been severely damaged by tuberculosis: Dr Pierson's report (of 23 April 1935) on Fitzgerald's $x$-rays was very gloomy indeed:

Examination of the chest shows that a much more extensive involvement of the lungs has taken place since the previous examination of June, 1933. An area of infiltration is seen in the upper left lobe and the centre of infiltration is not as dense as the peripheral portion, which would indicate the presence of cavity. Large areas of infiltration are seen in the right, middle and upper lobes. (Bruccoli 397)

It is reasonable to suppose that Fitzgerald was referring to this diagnosis of the doctor when in "The Crack-Up," he said: "I had sat in the office of a great doctor and listened to a grave sentence." And surely, this was the "news" that cracked him: "[I] cracked like an old plate as soon as I heard the news." The "news" from the doctor, which was like "a grave sentence" on Fitzgerald's life, devasted him. On the one hand, it made him bitter and cynical:

All in the same month I became bitter about such things as the sound of the radio, the advertisements in the magazines, the screech of tracks, the dead silence of the country-contemptuous at human softness, immediately (if secretively) quarrelsome towards hardnes-hating the night when I couldn't sleep and hating the day because it went towards night.

On the other hand, he became introspective and self-questioning. He began "to realize that for two years my life I had been drawing on resources that I did not possess, but I had been 
mortgaging myself physically and spiritually up to the hilt". A little self-examination of his conduct in the recent past revealed that he had been hypocritical in his personal relationships with other people: "I saw that for a long time I had not liked people and things, but only followed the rickety old pretence of liking. I saw that even my love for those closest to me was become only an attempt to love, that my casual relations-with an editor, a tobacco seller, the child of a friend, were only what I remembered I should do, from other days." Such realizations made him feel that he was akin to Job. And when a woman came to him in the "role of Job's comforter," he felt that he himself did not have access to her "vitality" that might redeem him too from his "world of bitterness."

In the next essay, "Pasting It Together" (399-404), Fitzgerald investigates how and why he had lost his "enthusiasm and vitality," why he "had become identified with the objects of [his] horror or compassion." He does not find nor does he offer answers to these questions, but he does feel that he is not alone in his "sodden-dark" state. He saw others, "a dozen men of honor and industry since the war" who had been similarly afflicted, and he decided to emulate their example in order to survive, to make a "sort of clean break" with the past. He would "slay" his past personality because he "could no longer fulfil the obligations that life had set" for him. He would "cease any attempts to be a person-to be kind, just or generous." Instead, he would "become a writer only."

Or a writer of a kind different from what he had hitherto been. Love had been his central theme, and he had sought to discover heroism in the tragic love stories that he wrote. But his personal experiences, which in his early years had directly or indirectly fed his stories, now made it almost impossible for him to look at love in positive terms. Zelda's almost incurable mental condition, together with his own alcoholism and ill-health made Fitzgerald almost despair of love. He had flirted and had had affairs with various women but he was never satisfied with any such relationships. For instance, he had made it clear to Beatrice Dance who had fallen in love with him that "he would never abandon Zelda whom he referred to as 'my invalid"' (Bruccoli 397-8). (I am reminded here of Robert Lowell who had made a similar remark to Martha Ritter, a twenty-one year old student who had fallen in love with him: "Unless he [Lowell] got sick, he said, he would never think of leaving [Elizabeth] Hardwick" [Hamilton 393].) Fitzgerald's breakdown made him realize that for several years he had been unable to love, that even his love for those "closest" to him was "only an attempt to love," a mere pretence. Since, in the words of Lionel Trilling, the "root of Fitzgerald's heroism is to be found, as it sometimes is in the tragic heroes, in his power of love" (244), Fitzgerald felt that the raison d'etre of his writing had suddenly vanished. This point is closely associated with his feeling that he must give up his other old ideals: in "Pasting It Together," he poignantly speaks of such a relinquishment:

A writer need have no such ideals unless he makes them for himself, and this one has quit [italics added]. The old dream of being an entire man in the Goethe-Byron-Shaw tradition, with an opulent American touch, a sort of combination of J. P. Morgan, Topham Beauclerk and St. Fransis of Assisi, has been relegated to the junk heap of the shoulder pads worn for one day on the Princeton football field and the overseas cap never worn overseas. 
So, he comes to the melancholy conclusion that, since "the natural state of the sentient adult is a qualified unhappiness," he must give up his earlier conviction that one must strive constantly only because it merely adds to "unhappiness in the end-that end comes to our youth and hope." Under the knowledge that his old idealisms and hopes are dead or irrelevant in the context of his present life, he decides to shed what he regards as the appurtenaces of his past self.

In the last essay, "Handle It with Care" (394-99), he further resolves to shake off his dependence on others, Edmund Wilson for intellectual support, Hemingway for artisitc inspiration and Gerald Murphy for social guidance. From now on he will cease giving of himself. Henceforth, he would only be a hard boiled writer, not a novelist in the old sense, for

I saw that the novel, which at my maturity was the strongest and supplest medium for conveying thought and emotion from one human being to another, was becoming subordinated to a mechanical and communal art that, whether in the hands of Hollywood merchants or Russian idealists, was capable of reflecting only the tritest thought, the most obvious emotion.

Fitzgerald ends this series of essays with a picture of himself as a man who is divested of all that he had been and all that he had believed in. He finds himself in a state of melancholia and helplessness because there is no direction for his life:

It was strange to have no self- - to be like a little boy left alone in a big house, who knew that he could do anything he wanted to do, but found that there was nothing that he wanted to do-

However, it is wrong to conclude that $T h e$ Crack-Up pieces are entirely negative and despairing as Dos Passos, Hemingway and several critics have believed them to be. They are more a relentless self-examination and self-searching with a view to moving forward. Fitzgerald himself saw them in penitential terms, not as heralding his death as a writer: he wrote to Hemingway, "[i]f I choose to write de profundis sometimes it doesn't mean I want friends praying aloud over my corpse" (Letters 311). Though the essays had appeared in February, March, and April 1936, he had written most of them out a couple of months earlier. He recovered soon, and in a letter, written in February (when the first of his essays appeared in Esquire), Fitzgerald informed his correspondent Julian Street that he had finished writing the "third article which completes the trilogy of depression," and went on to add that "things seem a little brighter, or at least the intensity of despair is fading, I can see the writing of them was a sort of catharsis..." (Letters 532-33). There is also an eye-witness account to corroborate this. After reading "The Crack-Up," the editor of the New York Post decided that a sensational story could be published about the breakdown of a famous novelist. Accordingly, he sent a reporter called Michael Mok who fraudulently managed to interview Fitzgerald who was then recovering from injuries that he had received in a swimming accident. Mok wrote a nasty account which was printed in a front-page article in the New York Post, under the heading, "The Poet-Prophet of the 
Post-War Neurotics." Fitzgerald was both depressed and outraged to read this account of himself. Maxwell Perkins sent Marjorie Rawlings (the author of the hugely successful The Yearling) to report on Fitzgerlad's condition. She lunched with him in October 1936 and sent back a reassuring assessment to Perkins:

I do not think you need to worry about him, physically or psychologically. He has thrown himself on the floor and shrieked himself blue in the face and pounded his heels - as lots of us do one way or another-but when it's over he'll be back to building his blocks again. (Turnbull 286)

More importantly, Fitzgerald felt in retrospect that "The Crack-Up" essays did not represent "a real nervous breakdown" but that they indicated a "spiritual change of life." He realized that such a change was necessary even though he was unprepared to make it. He was now faced with "a new set of conditions" to encounter which he would have to make "psychological adjustments" (Letters 589). Of course, it was a recognition of failure but even in his mood of depression and melancholia that resulted from such an awareness, Fitzgerald was encouraged by a recollection of failures that he had experienced and then transcended in his early life. In the last essay, "Handle It with Care," he speaks of the "two parallel experiences" of his youth, his failure at Princeton at football and the theatre club, and his disappointment over not having been able to go to the trenches as an army officer in 1918. Surely, the suggestion is that just as he had made "psychological adjustments" to meet new situations after those early failures, he would similarly come through this time also? I believe that these are the "hints" that Fitzgerald spoke of when, in February 1938 he wrote to Roger Garis that though "The Crack-Up" essays do not tell how he "gradually climbed out of the morass," there are "hints in [them] of what course it finally took" (Letters 569).

Unfortunately, in the succeeding years Fitzgerald was continually assailed by his own failing health, alcoholism, financial insecurity and Zelda's deteriorating condition. However, he regained mental composure and he was intellectually and artistically alert and willing. He had spent a day with Edmund Wilson in the fall of 1938 when the critic encouraged the novelist by telling him that everybody was waiting for his "later period to begin" (Turnbull 317). Fitzgerald had already embarked on a novel which was later to be published as The Last Tycoon. He had decided to write the novel about Hollywood and by May 1939 he was able to send a detailed synopsis to the editor of Colliers, Kenneth Littauer, in the hope that he would get an advance. In the synopsis, Fitzgerald explained that the hero of his new novel would be based on the Hollywood producer Irving Thalberg whom he had greatly admired. Thalberg, Fitzgerald wrote in the synopsis, was "one of the half dozen men [he had] known who were built on the grand scale" (Bruccoli 464). So the proposed novel was to be less burdened with Fitzgerald's own experiences and more detached, and hence different from his previous writings:

... I hope it will be entirely different-I hope it will be something new, arouse new emotions perhaps even a new way of looking at certain phenomena. I have set it safely in a period of five years ago to obtain detachment.... (Bruccoli 465) 
Thus, Fitzgerald had decided to make a conscious break with his past strategies as a writer. In "One Hundred False Starts," he had said, "I must start out with an emotion-one that's close to me and that I can understand" (356). And his friend Sara Murphy had echoed Hemingway's feelings on this matter when she told Fitzgerald, "I have always told you you havn't the faintest idea what anybody else but yourself is like ..." (Bruccoli 378). But in The Last Tycoon Fitzgerald was well on his way to surprising himself as well as his friends by creating Monroe Stahr who was based on another man whom he had admired. It was, of course, not easy for him to write differently. This is evident from the fact that though he had written 70,000 words (he had planned that the novel would be about 60,000 words), he had not so far succeeded in telling, as is clear from the outline that he had left behind, half the story. Unfortunately, he was able to complete, to his satisfaction, only six chapters before he was struck down by a heart attack.

Even in its fragmentary state, The Last Tycoon is a remarkable achievement. When it was published in 1941, Arnold Gingrich remarked that "The Last Tycoon is very fine. And don't let that word 'unfinished' scare you away from it. It is unfinished but the way Shubert's Unfinished Symphony is" (20). Edmund Wilson, who had edited the book, noted in his Foreword that he thought it was "even in its imperfect state, Fitzgerald's most mature piece of work" (vi). Wilson's evaluation of the novel is particularly significant because it was he who had provided "a standard approach to Fitzgerald" by saying in 1922 that he lacked intelligence and aesthetic sophistication: “. . . he had been given imagination without intellectual control of it: he had been given a gift of expression without very many clear ideas to express" (Bruccoli 165).

In his last novel, Fitzgerald seems to have mastered many of the shortcomings of his earlier writings and was ready to embody convincingly in The Last Tycoon the tragic ideal with which he had started his career as a writer. Soon after the publication of This Side of Paradise (1920), he had told President Hibben of Princeton of his belief "that life is too strong and remorseless for the sons of men" (Turnbull 311), and only a few months before he died, he wrote a letter to his daughter in which he defined "the wise and tragic sense of life:

By this I mean the thing that lies behind all great careers, from Shakespeare's to Abraham Lincoln's, and as far back as there are books to read-the sense that life is a cheat and its conditions are those of defeat, and that the redeeming things are not "happiness and pleasure" but the deeper satisfactions that come out of struggle. (Letters 96)

After having gone through the excruciating experiences which "The Crack-Up" essays record, Fitzgerald was at last able to envision a hero, Monroe Stahr, through whose life and experiences he could convey his "wise and tragic sense of life." Stahr is perhaps the most objective of Fitzgerald's heroes. He, therefore, can be described as the creation of Fitzgerald, the "writer only"- to borrow the words from "Pasting It Together." But before the "writer" could fully accomplish the task, the man in him was overtaken by life. 


\section{Works Cited}

Bruccoli, Matthew. Some Sort of Grandeur: The Life of F. Scott Fitzgerald. London: Hodder and Stoughton, 1981.

Fitzgerald, F. Scott. The Letters. Ed. Andrew Turnbull. London: Bodley Head, 1963. . The Bodley Head Scott Fitzgerald: This Side of Paradise, The Crack-Up and Other Autobiographical Pieces. Vol. 3. London: Bodley Head, 1960. The Notebooks of F. Scott Fitzgerald. Ed. Matthew Bruccoli. New York: Harcourt Brace, 1972.

Gingrich, Arnold. "F. Scott Fitzgerald's Final Novel of a Bygone Era." Chicago Daily News, December 3, 1941: 20.

Hamilton, Ian. Robert Lowell: A Biography. London: Faber, 1983.

Hemingway, Enest. A Moveable Feast. London: Jonathan Cape, 1964. . Selected Letters 1917-1961. Ed. Carlos Baker. New York: Scribners, 1981.

Hindus, Milton. F Scott Fitzgerald: An Introduction and Interpretation. New York: Barnes and Noble, 1968.

Mizener, Arthur, ed. F. Scott Fitzgerald. Englewood Cliffs: Prentice-Hall, 1965.

Trilling, Lionel. The Liberal Imagination. London: Secker and Warburg, 1951.

Turnbull, Andrew. Scott Fitzgerald. 1962. Harmondsworth: Penguin, 1970.

Wescott, Glenway. "The Moral of Scott Fitzgerald." The New Republic, February 17, 1941: 213-17.

Wilson, Edmund, ed. Three Novels of F Scott Fitzgerald. New York: Scribner, 1953. 